\title{
Uptake of Mn and Zn by Cucumber Grown in Closed Hydroponic Systems as Influenced by the Mn and Zn Concentrations in the Supplied Nutrient Solution
}

\author{
Constantinos Tzerakis \\ National Agricultural Research Foundation, Institute of Subtropical and \\ Olive Crops of Chania, Agrokipio, 73100 Chania, Greece
}

Dimitrios Savvas ${ }^{1}$

Agricultural University of Athens, Department of Crop Science, Iera Odos 75, 11855 Athens, Greece

Nick Sigrimis

Agricultural University of Athens, Department of Agricultural Engineering, Iera Odos 75, 11855 Athens, Greece

\section{Georgios Mavrogiannopoulos}

Agricultural University of Athens, Department of Agricultural Constructions, Iera Odos 75, 11855 Athens, Greece

Additional index words. accumulation, Cucumis sativus, manganese, nutrient uptake, soilless culture, zinc

\begin{abstract}
The objective of the present experiment was to estimate the uptake of manganese $(\mathrm{Mn})$ and zinc $(\mathrm{Zn})$ by cucumber in closed hydroponic systems at different $M n$ and $Z n$ concentrations in the recycled nutrient solution under Mediterranean climatic conditions. The obtained data might be used to manage Mn and $\mathrm{Zn}$ supply in closed hydroponic crops of cucumber grown in Mediterranean greenhouses and avoid their accumulation to toxic levels. Four Mn levels $(10,40,80,120 \mu M)$ at a standard $Z n$ concentration $(6 \mu M)$ and four $Z n$ levels $(6,20,40,60 \mu M)$ at a standard Mn concentration $(10 \mu M)$ in the solution supplied to compensate for nutrient and water uptake by plants were applied as experimental treatments. The actual uptake concentrations of $\mathrm{Mn}$ and $\mathrm{Zn}$ were estimated by applying two different methods. The first method was based on the removal of $\mathrm{Mn}, \mathrm{Zn}$, and water from the recycling nutrient solution, whereas the second method was based on the total quantities of $\mathrm{Mn}$ and $\mathrm{Zn}$ that were recovered in plant biomass in combination with the total water uptake. Both methods gave similar uptake concentrations for $M n$ in the low-Mn supply level and $\mathrm{Zn}$ in all $\mathrm{Zn}$ levels. However, in the three higher Mn supply levels, the values estimated on the basis of nutrient removal from the recirculating nutrient solution were significantly higher than those found by measuring the total Mn content in plant biomass. These discrepancies in the three high-Mn treatments were possibly caused by partial immobilization of Mn by oxidizing bacteria in the nutrient solution.
\end{abstract}

There is an increasing need in hydroponic systems to recirculate and reuse nutrient solutions (NS) so as to avoid contamination of groundwater by fertilizer residues and reduce the production cost (Gutiérrez et al., 2007; Van Os et al., 2008). However, excessive supply of any nutrient to cultivated plants in systems with nutrient solution recirculation leads inevitably to its accumulation in the root zone and to harmful levels for

Received for publication 21 Dec. 2012. Accepted for publication 28 Jan. 2013.

${ }^{1}$ To whom reprint requests should be addressed; e-maildsavvas@aua.gr. plant growth and yield (Carmassi et al., 2005; Massa et al., 2011). When macronutrients accumulate in the recycled nutrient solution, the electrical conductivity (EC) in the latter increases gradually, thereby alarming growers, who can decrease the rates of added fertilizers. However, the contribution of micronutrients to the $\mathrm{EC}$ of the recycled NS is extremely low even when their concentration in the NS reaches toxic levels (Sonneveld, 2002). Therefore, an accumulation of micronutrients in the NS to toxic levels is not perceived by growers before the occurrence of visible toxicity symptoms. Thus, to avoid toxicities of micronutrients in closed hydroponic systems, it is important to understand how their uptake is influenced by their concentration in the nutrient solutions used to feed the cultivated plants.

In most studies that address plant responses or physiological mechanisms underlying micronutrient toxicity in hydroponics, constant nutrient levels were applied, because they enable a better interpretation of the results (Rouphael et al., 2008; Shi and Zhu, 2008; Shi et al., 2006). However, in closed hydroponic systems used for commercial purposes, plants may be faced with a gradual accumulation of micronutrients (Adams, 2002). For this reason, it is important to know the possible patterns of micronutrient accumulation in closed hydroponic systems and their impacts on micronutrient uptake.

In closed hydroponics, the volume of water introduced to the system is essentially equal to that removed through transpiration if all the drainage solution is consistently recycled. In such systems, the input ratio between the mass of a nutrient and the volume of water should be equal to the corresponding nutrient-to-water uptake ratio by the plants, henceforth termed "uptake concentration," so as to avoid accumulation (Sonneveld and Voogt, 2009). However, the input ratio between the mass of a nutrient and the volume of water is equal to the concentration of this nutrient in the solution supplied to the closed hydroponic system to compensate for nutrient and water uptake by plants.

Based on research carried out in The Netherlands, De Kreij et al. (1999) and Sonneveld and Voogt (2009) published recommendations for $\mathrm{Mn}$ and $\mathrm{Zn}$ levels in NS used in closed hydroponic crops of cucumber to compensate for plant uptake. It is not clear if these recommendations are valid when cucumber is grown under dissimilar climatic conditions than those prevailing in The Netherlands, because the nutrient uptake responds differently to changes in greenhouse microclimate than the water uptake (Adams, 2002). Dissimilarities in the greenhouse microclimate may arise also from differences in heating practices. Heating is essential when greenhouse cucumber is grown at high latitudes but uncommon when grown under mild and dry climatic conditions (Castilla and Montero, 2008). Thus, differences in heating practices may further restrict the validity of Dutch recommendations on $\mathrm{Mn}$ and $\mathrm{Zn}$ supply in closed hydroponic crops of cucumber when these are located in areas characterized by mild winter and dry hot summer conditions. However, data indicating uptake ratios between masses of $\mathrm{Mn}$ or $\mathrm{Zn}$ and volume of water in cucumber crops grown hydroponically under mild winter and dry summer conditions, as those prevailing in the Mediterranean basin, are not available in the international scientific literature.

Cucumber is susceptible to manganese and zinc toxicities (Wang, 1987). Accumulation of $\mathrm{Mn}$ and $\mathrm{Zn}$ leading to corresponding toxicities is likely to occur in closed hydroponic systems if their supply is not efficiently tailored to their uptake. To avoid this situation in closed hydroponic crops of cucumber 
cultivated under mild winter and dry summer conditions, the $\mathrm{Mn}$ and $\mathrm{Zn}$ concentrations in the supplied NS should be based on experimental data originating from similar climatic zones. Therefore, the present study was designed to estimate optimal $\mathrm{Mn}$ and $\mathrm{Zn}$ uptake concentrations for cucumber crops grown under mild winter and dry summer conditions as those prevailing in the Mediterranean basin. These data might be used to optimize the composition of nutrient solutions supplied to closed hydroponic crops of cucumber to compensate for nutrient and water uptake when the plants are cultivated under climatic conditions characterized by mild winter and dry summer. Furthermore, to validate the data gained by measuring the removal of $\mathrm{Mn}$ and $\mathrm{Zn}$ from the recirculating solution, a quantitative assessment of the total amounts of $\mathrm{Mn}$ and $\mathrm{Zn}$ accumulated in the plant tissue of cucumber, including shoot and root, was performed.

\section{Materials and Methods} Rijk Zwaan BV, De Lier, The Netherlands) seedlings grown in rockwool cubes $(7.5 \mathrm{~cm}$ $7.5 \times 6.5 \mathrm{~cm})$ were transferred on 29 Sept. 2009 , at the stage of the third true leaf, into 24 channels corresponding to 24 independent hydroponic installations (experimental units). glasshouse located at Chania (lat. $35^{\circ} 29^{\prime} \mathrm{N}$, long. $24^{\circ} 02^{\prime} \mathrm{E}$ ), Greece, and the plants were grown under natural light conditions. The relative humidity fluctuated from $40 \%$ to $80 \%$ during the day and from $65 \%$ to $90 \%$ during the night, whereas the temperature ranged from 12 to $32{ }^{\circ} \mathrm{C}$ and 10.5 to $22{ }^{\circ} \mathrm{C}$, respectively. Each of the 24 experimental units consisted of one channel, $0.3 \mathrm{~m}$ in width, $6.5 \mathrm{~m}$ in length, and $0.05 \mathrm{~m}$ in height, an individual supply tank, a pump, and irrigation pipes so as to form a closed circuit in which a NS was constantly recirculating according to the principles of the nutrient film technique (Graves, 1983). pumped at a rate of $0.4 \mathrm{~m}^{3} \cdot \mathrm{h}^{-1}$ to each channel, whereas the total volume of the NS that was recirculating in each experimental unit amounted to $5 \mathrm{~L}$ per plant. In each unit, the nutrient and water uptake were compensated for by automatically supplying a replenishment NS from an individual tank using a floater so as to maintain a constant NS level in the supply tank. The NS that was consumed by the plants was recorded daily and replaced by refilling the replenishment tank. Thus, the daily consumption of NS was was adjusted once per day to 5.6 by adding appropriate amounts of nitric acid to the supply tank based on the actual $\mathrm{pH}$ level, which was measured using a portable $\mathrm{pH}$ meter. All channels were covered with blackwhite polyethylene sheets to avoid water evaporation. Each channel accommodated 12 cucumber plants, whereas the total volume of recirculating NS in each experimental unit
Cucumber (Cucumis sativus L. cv. Myrthos; The experiment was conducted in an unheated

The nutrient solution was automatically recorded. The $\mathrm{pH}$ in the recirculating NS (including both the solution contained in the supply tank and that flowing in the gullies) amounted to $60 \mathrm{~L}$. The crop density was 1.8 plants $/ \mathrm{m}^{2}$. The plants were pruned according to the umbrella training system (Klieber et al., 1993) and supported by plastic twine attached $2.5 \mathrm{~m}$ above the plant row on a horizontal wire.

Before transplanting, the 24 channels were randomly allocated into eight equal groups, which were supplied with eight NS corresponding to four Mn levels (10, 40, 80, $120 \mu \mathrm{M})$ at a standard $\mathrm{Zn}$ concentration $(6 \mu \mathrm{M})$ and four $\mathrm{Zn}$ levels $(6,20,40,60 \mu \mathrm{M})$ at a standard $\mathrm{Mn}$ concentration $(10 \mu \mathrm{M})$. The concentrations of all other nutrients in the eight treatment NS were as follows: $7.5 \mathrm{~mm}$ $\mathrm{K}^{+}, 5.5 \mathrm{mM} \mathrm{Ca}^{2+}, 2.25 \mathrm{mM} \mathrm{Mg}^{2+}, 1.00 \mathrm{~mm}$ $\mathrm{NH}_{4}^{+}, 17.00 \mathrm{~mm} \mathrm{NO}_{3}^{-}, 1.25 \mathrm{~mm} \mathrm{H}_{2} \mathrm{PO}_{4}^{-}$, $2.6 \mathrm{mM} \mathrm{SO}_{4}{ }^{2-}, 20 \mu \mathrm{M}$ iron (Fe), $1 \mu \mathrm{M}$ copper $(\mathrm{Cu}), 40 \mu \mathrm{M}$ boron $(\mathrm{B})$, and $0.5 \mu \mathrm{M}$ molybdenum (Mo). The EC and $\mathrm{pH}$ in these NS were $2.5 \mathrm{dS} \cdot \mathrm{m}^{-1}$ and 5.6, respectively. After transplanting, the nutrients and water that were absorbed by the plants were replenished daily by supplying replenishment NS with different nutrient concentrations than in the initial NS, excepting those of $\mathrm{Mn}$ and $\mathrm{Zn}$, which were identical. The concentrations of all other nutrients excepting $\mathrm{Mn}$ and $\mathrm{Zn}$ in the replenishment NS were as follows: $8 \mathrm{~mm} \mathrm{~K}^{+}$, $3.0 \mathrm{mM} \mathrm{Ca}^{2+}, 1.3 \mathrm{mM} \mathrm{Mg}^{2+}, 1.30 \mathrm{mM} \mathrm{NH}_{4}^{+}$, $13.75 \mathrm{mM} \mathrm{NO}_{3}^{-}, 1.25 \mathrm{mM} \mathrm{H} \mathrm{PO}_{4}^{-}, 1.3 \mathrm{~mm}$ $\mathrm{SO}_{4}{ }^{2-}, 15 \mu \mathrm{M} \mathrm{Fe}, 0.75 \mu \mathrm{M} \mathrm{Cu}, 25 \mu \mathrm{M} \mathrm{B}$, and $0.5 \mu \mathrm{M}$ Mo. The eight different replenishment NS were obtained by adding different amounts of $\mathrm{Mn}$ or $\mathrm{Zn}$ to a solution with the referenced composition. Forty-eight days after transplanting, the EC in the recirculating NS rose to higher levels than $2.7 \mathrm{dS} \cdot \mathrm{m}^{-1}$ in most experimental units. To prevent a further increase of the EC in the recirculating NS, the macronutrient concentrations were reduced in all replenishment NS, whereas the micronutrient concentrations were not altered. In particular, the concentrations of macronutrients in the four replenishment NS that were used after the first $50 \mathrm{~d}$ of cropping were as
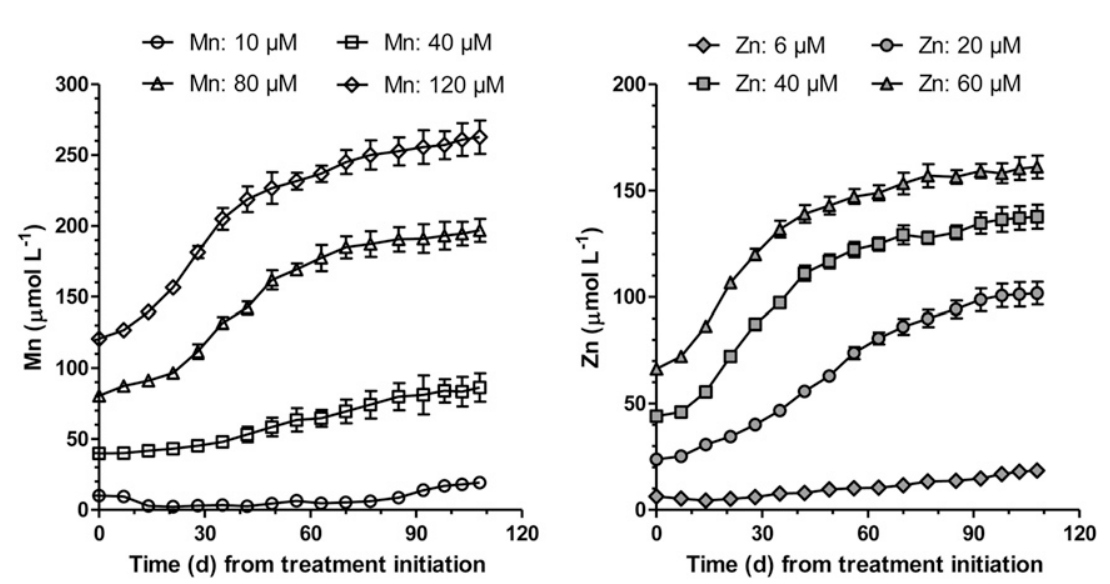

Fig. 1. Changes of manganese $(\mathrm{Mn})$ and zinc $(\mathrm{Zn})$ concentrations with time in recirculating nutrient solutions as influenced by the concentrations of $\mathrm{Mn}$ and $\mathrm{Zn}$ in the replenishment nutrient solutions introduced to closed-cycle hydroponic crops of cucumber to compensate for plant uptake. Vertical bars depict \pm SEMS of three measurements.

follows: $6.80 \mathrm{~mm} \mathrm{~K} \mathrm{~K}^{+}, 1.75 \mathrm{mM} \mathrm{Ca}^{2+}, 1 \mathrm{~mm}$ $\mathrm{Mg}^{2+}, 1.25 \mathrm{mM} \mathrm{NH}_{4}^{+}, 10.0 \mathrm{mM} \mathrm{NO}_{3}^{-}, 1.2 \mathrm{~mm}$ $\mathrm{H}_{2} \mathrm{PO}_{4}^{-}$, and $0.90 \mathrm{~mm} \mathrm{SO}_{4}{ }^{2-}$. The $\mathrm{pH}$ of the replenishment NS was always adjusted to 5.6 by adding nitric acid.

Harvesting of commercially ripe fruit started $33 \mathrm{~d}$ after transplanting and was repeated twice a week until the end of the experiment on 18 Jan. 2010 (110 d after transplanting). On each harvesting date, the total number and weight of harvested fruit were recorded separately in each experimental unit and subsequently representative samples were dried at $65{ }^{\circ} \mathrm{C}$ to constant weight to determine the fruit dry mass per plant.

Samples of recirculating NS were selected on a weekly basis from all experimental units to determine the actual $\mathrm{Mn}$ and $\mathrm{Zn}$ concentrations. Furthermore, the lower leaves that were removed from two selected plants per experimental unit during the experiment were always dried at $72{ }^{\circ} \mathrm{C}$ to constant weight to determine fresh weight (FW) and dry weight (DW). Subsequently, subsamples of the dried fruit and leaf samples were used for chemical analysis to determine the $\mathrm{Mn}$ and $\mathrm{Zn}$ concentrations. At the end of the experiment (18 Jan. 2010), the entire root system in each channel was removed for $\mathrm{FW}$ determination and part of the root was collected and used to determine the DW and tissue micronutrient concentrations. Furthermore, the FW and DW of stems and remaining leaves and fruit (mature, immature, and flowers) from the two selected plants per experimental unit were determined and the dried material was then used to measure $\mathrm{Mn}$ and $\mathrm{Zn}$ concentrations. The leaf, stem, fruit, and root samples were powdered using a blade mill, passed through a 40-mesh sieve, subjected to dry ashing in a muffle furnace at $550{ }^{\circ} \mathrm{C}$ for $5 \mathrm{~h}$, and used to extract $\mathrm{Mn}$ and $\mathrm{Zn}$ by means of $1 \mathrm{~N} \mathrm{HCl}$. The concentrations of $\mathrm{Mn}$ and $\mathrm{Zn}$ in both the nutrient solutions and the aqueous extracts of plant tissues were measured using an atomic absorption spectrophotometer (Perkin Elmer 3300; Perkin Elmer, Waltham, MA). 
Nutrient-to-water uptake ratios (uptake concentrations) for $\mathrm{Mn}$ and $\mathrm{Zn}$ were estimated by two independent approaches. The first approach was based on the removal of nutrients from the nutrient solution. In particular, the mean uptake concentration of the $x$ micronutrient $\left(C_{x u}\right.$ in $\mu \mathrm{mol} \cdot \mathrm{L}^{-1}$, where $\left.x=\mathrm{Mn}, \mathrm{Zn}\right)$ was determined for successive time intervals (every 3 weeks up to Day 42 after treatment initiation and every 2 weeks thereafter) using the following mass balance equation:

$$
C_{x u}=\frac{V_{r}\left(C_{x b i}-C_{x e i}\right)+V_{u i} C_{x a}}{V_{u i}}
$$

where $V_{r}(\mathrm{~L})$ denotes the total volume of the recirculating nutrient solution in each experimental unit (60 L in the present study), $V_{u i}(\mathrm{~L})$ denotes the total volume of NS that was taken up by the plants in each experimental unit during the $i$ time interval $(i=1 . .7), C_{x b i}$ and $C_{x e i}\left(\mu \mathrm{mol} \cdot \mathrm{L}^{-1}\right)$ denote the concentrations of the $x$ micronutrient in the recirculating nutrient solution on the first and the last day of the $i$ time interval $(\mathrm{i}=1 . .7)$, and $C_{x a}$ $\left(\mu \mathrm{mol} \cdot \mathrm{L}^{-1}\right)$ denotes the concentration of the $x$ micronutrient in the replenishment NS used in each treatment. The second approach was based on the amounts of the $x$ micronutrient recovered in the plant tissues and the mean volume of NS per plant that was absorbed by the crop in each experimental unit during the whole cropping period. According to this approach, the mean uptake concentrations of $\mathrm{Mn}$ and $\mathrm{Zn}\left(C_{x u}\right.$ in $\mu \mathrm{mol} \cdot \mathrm{L}^{-1}$, where $\left.x=\mathrm{Mn}, \mathrm{Zn}\right)$ were determined using the following equation:

$C_{x u}=\frac{C_{x r} B_{r}+C_{x s} B_{s}+\sum C_{x l i} B_{l i}+\sum C_{x f j} B_{f j}}{V_{u p}}$

where $C_{x r}, C_{x s}, C_{x l i}$, and $C_{x f i}$ denote the concentrations $\left(\mu \mathrm{mol} \cdot \mathrm{g}^{-1}\right)$ of the $x$ ion $(x=\mathrm{Mn}, \mathrm{Zn})$ in the root, stem, leaves, and fruit, respectively; $B_{r}, B_{s}, B_{l i}$, and $B_{f i}$ denote the root, stem, leaf, and fruit biomass (g/plant), respectively; and $V_{u p}$ denotes the total volume of NS (L per plant) that has been taken up by the crop in each experimental unit during the whole cropping period. The subscripts $i$ in $C_{x l i}$ and $C_{x f i}(i=$ $1 . .9)$ as well as $j$ in $B_{l j}$, and $B_{f j}(j=1 . .12)$ depict

\section{Leaf}

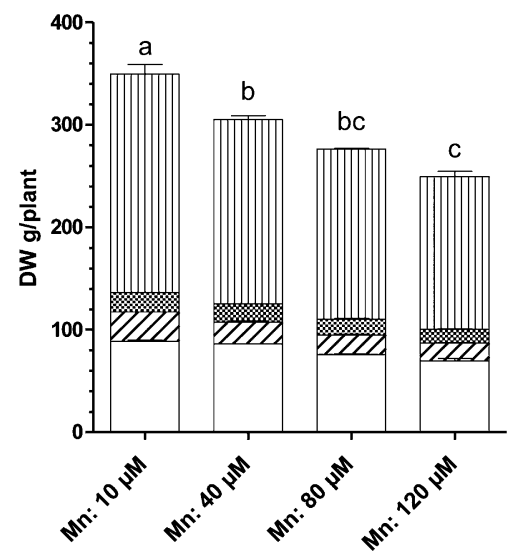

@ Root

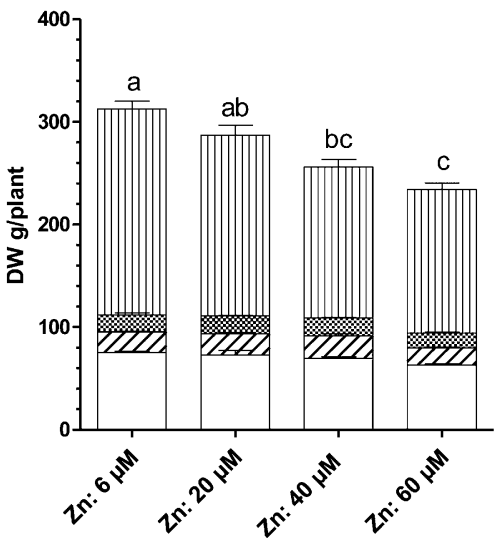

Fig. 2. Total dry plant biomass (DW) and partitioning between different parts of cucumber plants grown in closed-cycle hydroponic systems for $110 \mathrm{~d}$, as influenced by the concentrations of manganese (Mn) and zinc $(\mathrm{Zn})$ in the nutrient solutions introduced to the systems to compensate for plant uptake. In each graph, columns with no common letter indicate significant differences among means of three measurements $(P \leq 0.05)$.

$$
\multimap \mathrm{Mn}: 8 \mu \mathrm{M}
$$

$\triangle \mathrm{Mn}: 40 \mu \mathrm{M}$

Leaf $\mathrm{Mn}$

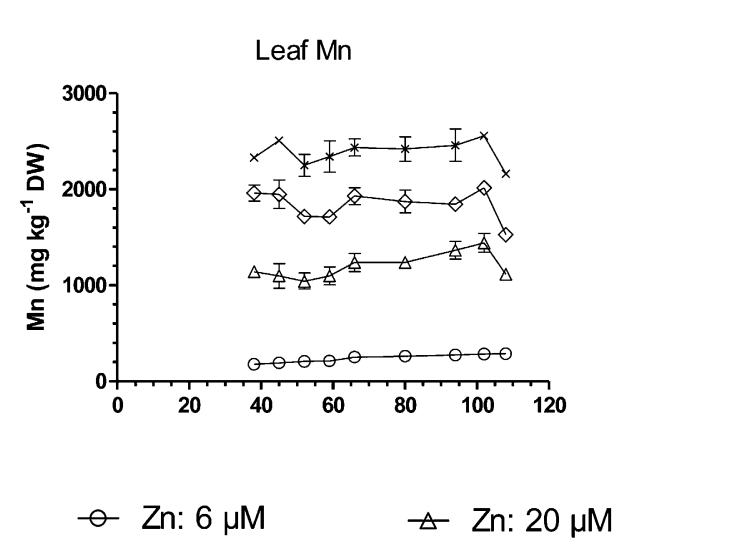

- Zn: $6 \mu \mathrm{M}$

$\triangle \mathrm{Zn}: 20 \mu \mathrm{M}$

Leaf $\mathrm{Zn}$

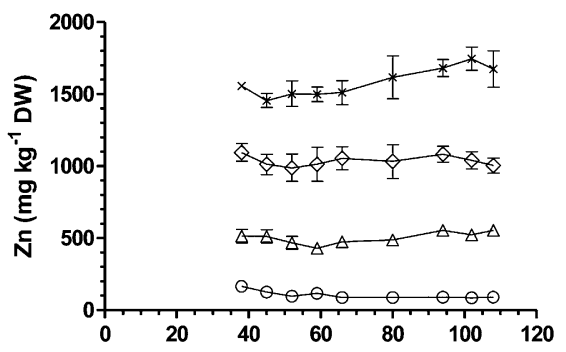

$\diamond \mathrm{Mn}: 80 \mu \mathrm{M}$

$* \mathrm{Mn}: 120 \mu \mathrm{M}$

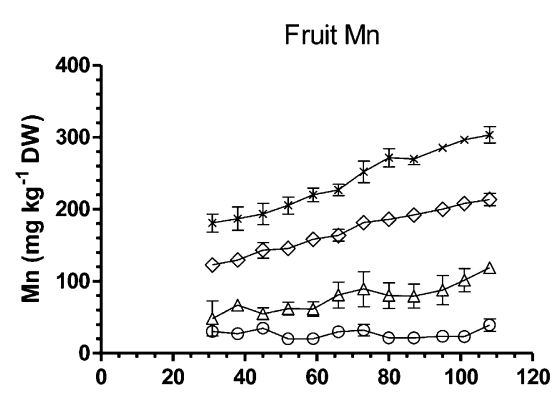

$\diamond \mathrm{Zn}: 40 \mu \mathrm{M}$

* Zn: $60 \mu \mathrm{M}$

Fruit Zn

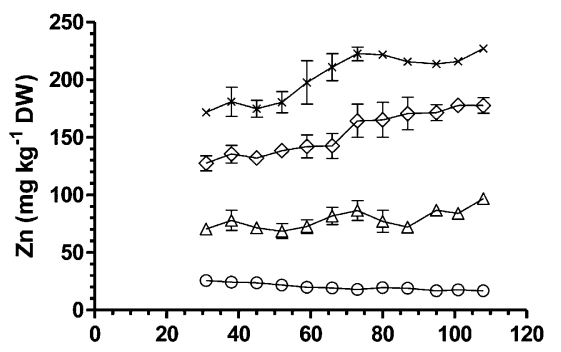

\section{Time (d) from treatment initiation}

Fig. 3. Concentrations of manganese (Mn) and zinc $(\mathrm{Zn})$ in the dry biomass (DW) of leaves and fruit removed from cucumber plants grown in closed-cycle hydroponic systems for $110 \mathrm{~d}$, as influenced by the concentrations of $\mathrm{Mn}$ and $\mathrm{Zn}$ in the nutrient solutions introduced to the systems to compensate for plant uptake. Vertical bars indicate \pm SEMS of three measurements. 
the sequence of sampling dates of fruit and older leaves during the cropping period.

\section{Results and Discussion}

The changes of Mn and $\mathrm{Zn}$ concentrations with time in the recirculating NS are shown in Figure 1. In the treatment with the lowest Mn concentration in the replenishment NS $(10 \mu \mathrm{M})$, the $\mathrm{Mn}$ level in the recirculating NS decreased sharply to $1.3 \mu \mathrm{M}$ during the initial $21 \mathrm{~d}$ after treatment initiation (DATI), ranged to levels below $7 \mu \mathrm{M}$ up to $70 \mathrm{DATI}$, which is a target Mn level for cucumber in the root zone according to De Kreij et al. (1999), and increased gradually thereafter up to $19 \mu \mathrm{M}$ 110 DATI. In the lowest $\mathrm{Zn}$ treatment $(6 \mu \mathrm{M})$, the $\mathrm{Zn}$ concentration in the recirculating NS decreased slightly from 6 to $5.2 \mu \mathrm{M}$ during the initial 21 DATI but increased constantly thereafter up to $18.6 \mu \mathrm{M}$ at crop termination (110 DATI). In the treatments with the three higher $\mathrm{Mn}$ and $\mathrm{Zn}$ concentrations, both $\mathrm{Mn}$ and $\mathrm{Zn}$ in the recirculating NS increased sharply up to 70 DATI, but subsequently they gradually leveled off to maximum threshold values following a convex pattern. Similar patterns of gradual ion accumulation up to maximum thresholds in closed-cycle hydroponic systems, owing to constant input of salts, have been observed also for sodium and chlorine (Baas et al., 1995; Savvas et al., 2005). When such a pattern of ion accumulation is observed, the maximum threshold concentration of the particular ion in the recirculating NS imposes as high an uptake concentration as the level of this ion in the replenishment NS (Varlagas et al., 2010). Consequently, the maximum $\mathrm{Mn}$ and $\mathrm{Zn}$ concentrations that were observed in the present study corresponded to as high uptake concentrations as the $\mathrm{Mn}$ and $\mathrm{Zn}$ levels, respectively, in the replenishment NS of the particular treatment. The increase of the $\mathrm{Mn}$ and $\mathrm{Zn}$ uptake concentrations with rising external $\mathrm{Mn}$ and $\mathrm{Zn}$ levels indicated that the ability of cucumber to control $\mathrm{Mn}$ and $\mathrm{Zn}$ uptake progressively declined. A descending ability of plants to prevent Mn toxicity by maintaining constant $\mathrm{Mn}$ absorption rates as the external Mn concentration is rising was reported by El-Jaoual and Cox (1998). Nevertheless, the ability of plants to control nutrient uptake and avoid toxicities depends on plant genotype. Denny and Wilkins (1987) found that tolerant genotypes of Betula spp. trees to high $\mathrm{Zn}$ concentration could maintain control of $\mathrm{Zn}$ uptake within a wider range of external $\mathrm{Zn}$ concentrations than less tolerant genotypes could do.

The root, stem, leaf, and fruit biomass ( $B_{r}$, $B_{s}, B_{l i}$, and $B_{f j}$, respectively, in Eq. 2) is shown in Figure 2. The total plant biomass was reduced when the $\mathrm{Mn}$ or $\mathrm{Zn}$ concentration in the replenishment NS that was supplied to cucumber grown in a closed-cycle hydroponic system was $40 \mathrm{~mm}$ or higher. These results are in agreement with previous reports of Shi and Zhu (2008) and Tzerakis et al. (2012). Nevertheless, the reduction in plant biomass was lower than $25 \%$ even at the highest $\mathrm{Mn}$ and $\mathrm{Zn}$ levels in the replenishment NS, which raised the concentrations of $\mathrm{Mn}$ and $\mathrm{Zn}$ in the recirculating NS to $\approx 270 \mathrm{~mm}$ and $170 \mathrm{~mm}$, respectively.

The concentrations of $\mathrm{Mn}$ and $\mathrm{Zn}$ in the root, stem, leaves, and fruit $\left(C_{x r}, C_{x s}, C_{x l i}\right.$, and $C_{x f f}$, respectively, in Eq. 2) are shown in Figures 3 and 4. The accumulation of $\mathrm{Mn}$ and $\mathrm{Zn}$ in the root zone led to constantly increased concentrations of these ions in the leaves and the fruit during the cropping period (Fig. 3) as well as in roots and stem sampled at crop termination (Fig. 4), in agreement with a previous report of Sonneveld and de Bes (1984).

The uptake concentrations of $\mathrm{Mn}$ and $\mathrm{Zn}$ that were estimated by recording their
ख $\mathrm{Mn}: 10 \mu \mathrm{M} \quad \mathbf{M n}: 40 \mu \mathrm{M}$

Stem Mn

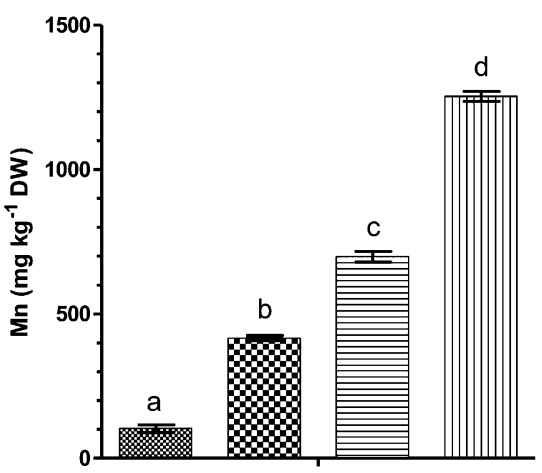

एس) Zn: $6 \mu \mathrm{M}$

WIII: $20 \mu \mathrm{M}$

Stem Zn

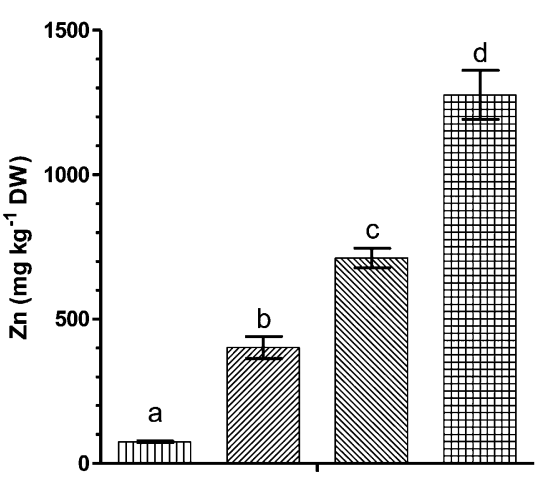

$\mathrm{Mn}: 80 \mu \mathrm{M}$

Root Mn

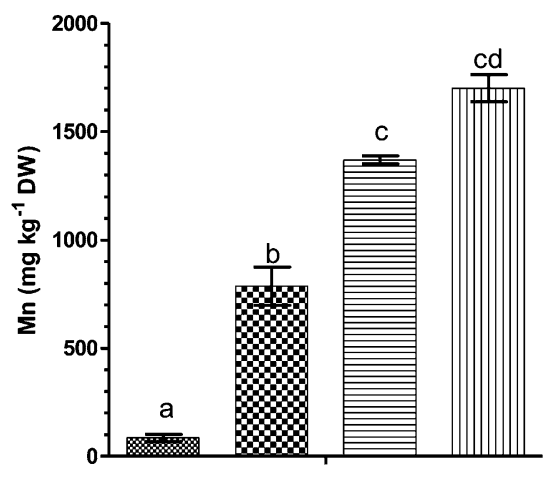

Zn: $40 \mu \mathrm{M} \quad$ 巴 Zn: $60 \mu \mathrm{M}$

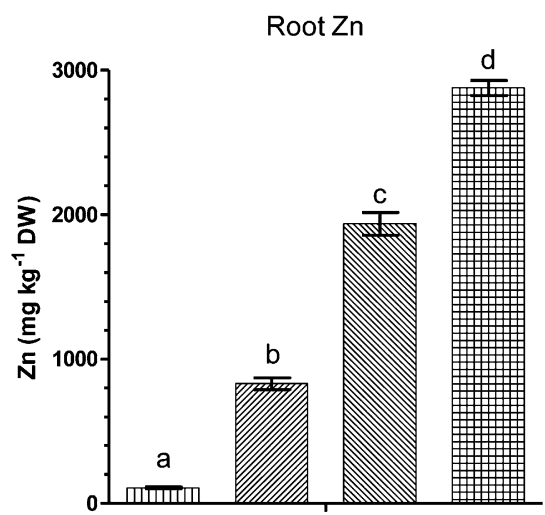

Fig. 4. Concentrations of manganese (Mn) and zinc ( $\mathrm{Zn}$ ) in the dry biomass (DW) of stem and root of cucumber grown in closed-cycle hydroponic systems for $110 \mathrm{~d}$, as influenced by the concentrations of $\mathrm{Mn}$ and $\mathrm{Zn}$ in the nutrient solutions introduced to the systems to compensate for plant uptake. In each graph, columns with no common letter indicate significant differences among means of three measurements $(P \leq 0.05)$. 
removal from the recirculating NS (Gorbe and Calatayud, 2010) as well as the water uptake are shown in Figure 5(i). The calculations were performed by substituting values shown in Figure 1 for $C_{x b i}$ and $C_{x e i}$, the recorded volumes of absorbed nutrient solution at each time interval (data not shown) for $V_{u i}$, the total volume of recirculating NS (72 L) for $V_{r}$, and the treatment concentrations of $\mathrm{Mn}$ and $\mathrm{Zn}$ for $C_{x a}$ in Eq. (1). When measuring removal of ions and water from nutrient solutions supplied to plants in closed hydroponic systems, as is the case when Eq. (1) is used, the obtained ratios constitute apparent uptake concentrations (Pardossi et al., 2006). To test whether the apparent uptake concentrations of $\mathrm{Mn}$ and $\mathrm{Zn}$ that were obtained using Eq. (1) represented net nutrient-towater uptake ratios in cucumber, the latter were estimated also using Eq. (2), which is based on determination of the total amounts of these micronutrients in plant tissues (Gorbe and Calatayud, 2010). The obtained results are shown in Figure 5(ii). Both estimation methods showed that the $\mathrm{Mn}$ and $\mathrm{Zn}$ uptake concentrations by cucumber were highly affected by the levels of these micronutrients in the supplied NS, in agreement with previous results reported by Sonneveld and de Bes (1984). Furthermore, both estimation methods resulted in similar $\mathrm{Zn}$ uptake concentrations at all levels of $\mathrm{Zn}$ in the recirculating NS. However, the Mn uptake concentrations that were estimated by tissue analysis were significantly lower at the three high-Mn levels in the replenishment NS than those obtained by measuring Mn removal from the recirculating NS. The higher apparent Mn uptake concentrations than those estimated on the basis of $\mathrm{Mn}$ recovered from the total plant biomass may have been caused by partial immobilization of soluble $\mathrm{Mn}$ by oxidizing bacteria, which is a common phenomenon in aerated nutrient solutions (Bromfield, 1978). The bacteria develop rapidly as $\mathrm{pH}$ increases to higher levels than $\approx 5$ and can oxidize an appreciable part of the applied bivalent $\mathrm{Mn}$, which precipitates as manganese oxide (Sonneveld and Voogt, 1980). In the present study, the $\mathrm{pH}$ in the recirculation solution fluctuated between 5.6 and 6.8 during the cropping period (data not shown). Thus, when the uptake concentrations of $\mathrm{Mn}$ were estimated by recording $\mathrm{Mn}$ removal from the recirculating NS, the immobilized Mn could not be distinguished from that absorbed by the plants, and thus higher values were obtained in comparison with those based on the Mn recovered from plant tissues. A decrease of soluble Mn resulting from microbial oxidation of $\mathrm{Mn}$ in the recirculating NS is beneficial when $\mathrm{Mn}$ is supplied at excessively high rates but potentially harmful if $\mathrm{Mn}$ is supplied at rates close to the standard uptake requirements of cucumber plants.

The total amounts of $\mathrm{Mn}$ and $\mathrm{Zn}$ that were supplied and removed from the recirculating NS after $110 \mathrm{~d}$ of cucumber cultivation were compared with those recovered from the plant tissues (Fig. 6). In all treatments, the quantities of $\mathrm{Zn}$ that were supplied and removed from the recirculating NS were similar with those recovered from the plant tissues. These results indicate that both methods are credible and can be used to estimate nutrient uptake in closed-cycle hydroponic systems, in agreement with previous reports (Barak et al., 1996; Kläring, 2001). However, at the three high-Mn supply treatments, the amounts of $\mathrm{Mn}$ that were removed from the recirculating NS were higher than those recovered from the plant tissues. These discrepancies, which possibly result from partial $\mathrm{Mn}$ immobilization by Mn-oxidizing bacteria, indicate that an assessment of $\mathrm{Mn}$ uptake in water culture
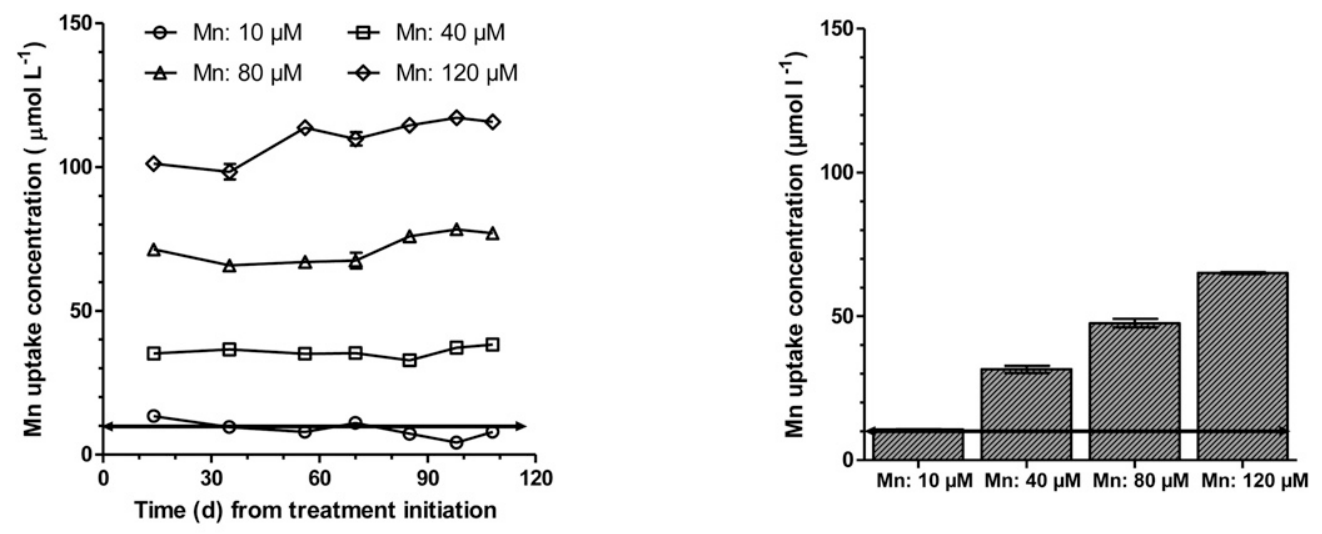

(i) $\longleftrightarrow$ Suggested concentration by $\longleftrightarrow$ Sonneveld and Voogt, 2009

(ii)
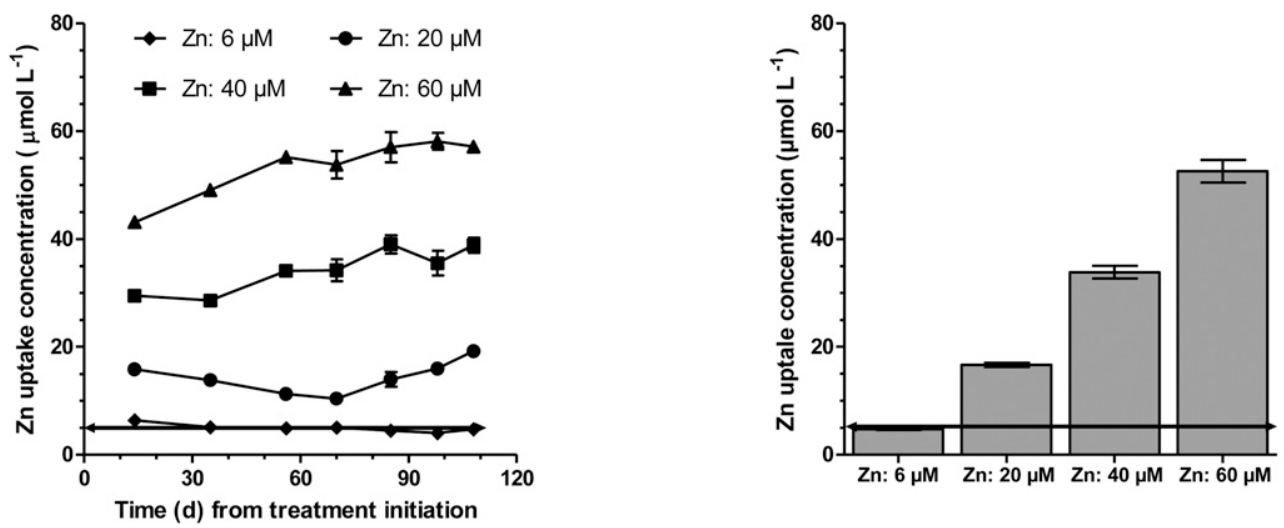

Fig. 5. Estimated uptake concentrations of manganese $(\mathrm{Mn})$ and zinc $(\mathrm{Zn})$ by cucumber plants grown in closed-cycle hydroponic systems for $110 \mathrm{~d}$ using two different methods, specifically: (i) based on the removal from the recirculating nutrient solution (NS) and (ii) based on the total amounts recovered in the plant biomass. Vertical bars indicate \pm SEMS of three measurements. The horizontal lines indicate Dutch recommendations (Sonneveld and Voogt, 2009) for Mn and Zn concentrations in nutrient solutions supplied to closed hydroponic crops of cucumber to compensate for plant uptake. 


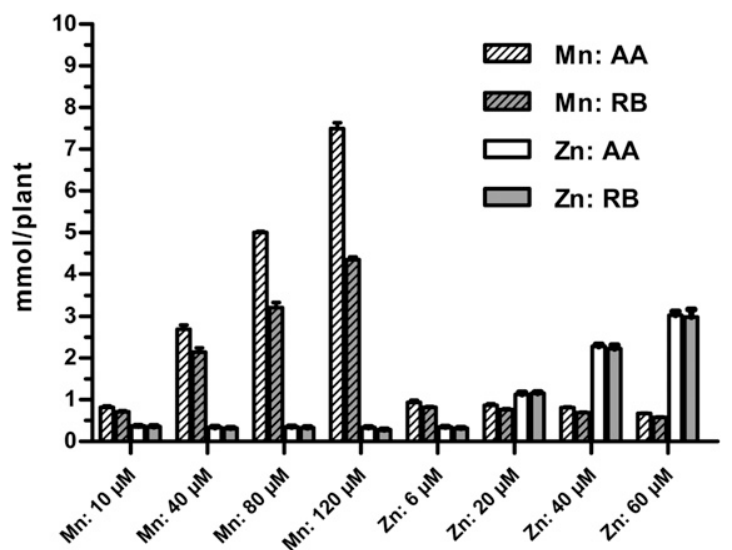

Fig. 6. Apparent uptake (AA) of manganese (Mn) and zinc ( $\mathrm{Zn}$ ) from the nutrient solution vs. quantities recovered in the total biomass (RB) of cucumber plants grown in closed-cycle hydroponic systems for $110 \mathrm{~d}$, as influenced by the concentrations of $\mathrm{Mn}$ and $\mathrm{Zn}$ in the nutrient solutions introduced to the systems to compensate for plant uptake. Vertical bars indicate \pm SEMS of three measurements.

experiments should be based on total Mn deposition in plant tissues and not on $\mathrm{Mn}$ removal from the external nutrient medium.

The Mn uptake concentrations in the low Mn treatment $(10 \mu \mathrm{M})$ reached occasionally levels between 11 to $13.5 \mu \mathrm{M}$ in the replenishment NS during the first 70 DATI. These values were higher than the Mn levels in the replenishment NS and this discrepancy between Mn input and Mn output resulted in too low Mn concentrations in the recirculating NS during that period. However, thereafter, the Mn uptake concentration decreased to levels up to $4 \mu \mathrm{M}$. These findings stress the necessity to apply Mn concentrations of $\approx 12$ to $14 \mu \mathrm{M}$ in replenishment NS used in closedcycle hydroponic cultivations of cucumber under Mediterranean climatic conditions during the first two months of growing and decrease this level to or slightly below $10 \mu \mathrm{M}$ thereafter. These recommendations are not much different from the level of $10 \mu \mathrm{M}$, which is suggested by De Kreij et al. (1999) and Sonneveld and Voogt (2009) based on data obtained under Dutch climatic conditions. The $\mathrm{Zn}$ uptake concentrations in the low $\mathrm{Zn}(6 \mu \mathrm{M})$ treatment amounted to $6.4 \mu \mathrm{M}$ during the initial 21 DATI but dropped to levels between 4 to $5 \mu \mathrm{M}$ thereafter, thereby imposing a $\mathrm{Zn}$ accumulation in the root zone, as shown in Figure 1. Thus, a $\mathrm{Zn}$ concentration of 6 to $7 \mu \mathrm{M}$ in replenishment NS during the initial 3 weeks of growing followed by a reduction to $5 \mu \mathrm{M}$ and presumably to $4 \mu \mathrm{M}$ thereafter seems to be the most appropriate policy for closed-cycle hydroponic cultivations of cucumber when cultivated under Mediterranean climatic conditions. De Kreij et al. (1999) and Sonneveld and Voogt (2009) recommend a $\mathrm{Zn}$ concentration of $5 \mu \mathrm{M}$ for replenishment NS supplied to cucumber when cultivated in closed hydroponic systems under Dutch climatic conditions.

\section{Conclusions}

The $\mathrm{Mn}$ and $\mathrm{Zn}$ uptake concentrations by cucumber grown in recirculating nutrient solution were calculated by means of two independent methods. The first method was based on the removal of $\mathrm{Mn}, \mathrm{Zn}$, and water from the recirculating nutrient solution, whereas the second method was based on the total quantities of $\mathrm{Mn}$ and $\mathrm{Zn}$ that were recovered from the plant biomass and the total water uptake. Both methods gave similar uptake concentrations for $\mathrm{Mn}$ in the low Mn supply level and $\mathrm{Zn}$ in all $\mathrm{Zn}$ supply levels. However, in the three higher $\mathrm{Mn}$ supply levels, the values estimated on the basis of nutrient removal from the recirculating nutrient solution were significantly higher than those found by measuring the total Mn content in plant biomass. These discrepancies in the three high-Mn treatments were presumably the result of partial immobilization of $\mathrm{Mn}$ by oxidizing bacteria in the nutrient solution. Based on the estimated Mn uptake concentrations, a Mn level of 12 to $14 \mu \mathrm{M}$ during the first two months of growing, followed by a decrease to or slightly below $10 \mu \mathrm{M}$ thereafter, is suggested for NS supplied to closed-cycle hydroponic cultivations of cucumber under Mediterranean climatic conditions. The corresponding recommendations for $\mathrm{Zn}$ range from 6 to $7 \mu \mathrm{M}$ during the initial 3 weeks of growing followed by a reduction to $5 \mu \mathrm{M}$ and presumably to $4 \mu \mathrm{M}$ thereafter.

\section{Literature Cited} ponics, p. 211-261. In: Savvas, D. and H.C. Passam (eds.). Hydroponic production of vegetables and ornamentals. Embryo Publications, Athens, Greece.

Baas, R., H.M.C. Nijssen, T.J.M. van der Berg, and of carnation (Dianthus caryophyllus L.) and gerbera (Gerbera jamesonii L.) in a closed nutrient system as affected by sodium chloride. Sci. Hort. 61:273-284. Peterson. 1996. Measurement of short-term nutrient uptake rates in cranberry by aeroponics. Plant Cell Environ. 19:237-242.
Adams, P. 2002. Nutritional control in hydroM.G. Warmenhoven. 1995. Yield and quality

Barak, P., J.D. Smith, A.R. Krueger, and L.A
Bromfield, S.M. 1978. The effect of manganese oxidizing bacteria and $\mathrm{pH}$ on the availability of manganous ions and manganese oxides to oats in nutrient solutions. Plant Soil 49:23-29.

Carmassi, G., L. Incrocci, R. Maggini, F. Malorgio, F. Tognoni, and A. Pardossi. 2005. Modeling salinity build-up in recirculating nutrient solution culture. J. Plant Nutr. 28:431-445.

Castilla, N. and J.I. Montero. 2008. Environmental control and crop production in Mediterranean greenhouses. Acta Hort. 797:25-36.

De Kreij, C., W. Voogt, and R. Baas. 1999. Nutrient solutions and water quality for soilless cultures. Brochure 196. Research Station for Floriculture and Glasshouse Vegetables (PBG), Naaldwijk, The Netherlands.

Denny, H.J. and D.A. Wilkins. 1987. Zinc tolerance in Betula ssp. I. Effect of external concentration of zinc on growth and uptake. New Phytol. 106:517-524.

El - Jaoual, T. and D.A. Cox. 1998. Manganese toxicity in plants. J. Plant Nutr. 21:353-386.

Gorbe, E. and A. Calatayud. 2010. Optimization of nutrition in soilless systems: A review. Adv. Bot. Res. 53:193-245.

Graves, C.J. 1983. The nutrient film technique. Hort. Rev. 5:1-44.

Gutiérrez, M., S. Alegret, R. Cáceres, J. Casadesús, O. Marfà, and M. del Valle. 2007. Application of a potentiometric electronic tongue to fertigation strategy in greenhouse cultivation. Comput. Electron. Agr. 57:12-22.

Kläring, H.P. 2001. Strategies to control water and nutrient supplies to greenhouse crops. A review. Agronomie 21:311-321.

Klieber, A., W.C. Lin, P.A. Jolliffe, and J.W. Hall. 1993. Training systems affect canopy light exposure and shelf life of long English cucumber. J. Amer. Soc. Hort. Sci. 118:786790.

Massa, D., L. Incrocci, R. Maggini, C. Bibbiani, G. Carmassi, F. Malorgio, and A. Pardossi. 2011. Simulation of crop water and mineral relations in greenhouse soilless culture. Environ. Model. Softw. 26:711-722.

Pardossi, A., F. Malorgio, L. Incrocci, G. Carmassi, R. Maggini, D. Massa, and F. Tognoni. 2006. Simplified models for the water relations of soilless cultures: What they do or suggest for sustainable water use in intensive horticulture. Acta Hort. 718:425-434.

Rouphael, Y., M. Cardarelli, E. Rea, and G. Colla. 2008. Grafting of cucumber as a means to minimize copper toxicity. Environ. Exp. Bot. 63:49-58.

Savvas, D., V.A. Pappa, A. Kotsiras, and G. Gizas. 2005. $\mathrm{NaCl}$ accumulation in a cucumber crop grown in a completely closed hydroponic system as influenced by $\mathrm{NaCl}$ concentration in irrigation water. Europ. J. Hort. Sci. 70:217223.

Shi, Q. and Z. Zhu. 2008. Effects of exogenous salicylic acid on manganese toxicity, element contents and antioxidative system in cucumber. Environ. Exp. Bot. 63:317-326.

Shi, Q., Z. Zhu, M. Xu, Q. Qian, and J. Yu. 2006. Effect of excess manganese on the antioxidant system in Cucumis sativus L. under two light intensities. Environ. Exp. Bot. 58:197-205.

Sonneveld, C. 2002. Composition of nutrient solutions, p. 179-212. In: Savvas, D. and H.C. Passam (eds.). Hydroponic production of vegetables and ornamentals. Embryo Publ., Athens, Greece.

Sonneveld, C. and S.S. de Bes. 1984. Micro nutrient uptake of glasshouse cucumbers grown on rockwool. Commun. Soil Sci. Plant Anal. 15:519-535. 
Sonneveld, C. and S.J. Voogt. 1980. The application of manganese in nutrient solutions for tomatoes grown in a recirculating system. Acta Hort. 98:171-178.

Sonneveld, C. and W. Voogt. 2009. Plant nutrition of greenhouse crops. Springer, Dordrecht, The Netherlands; Heidelberg, Germany; London, UK; New York, NY.

Tzerakis, C., D. Savvas, and N. Sigrimis. 2012. Responses of cucumber grown in recirculating nutrient solution to gradual $\mathrm{Mn}$ and $\mathrm{Zn}$ accumulation in the root zone owing to excessive supply via the irrigation water. J. Plant Nutr. Soil Sci. 175:125-134.

Van Os, E., T.H. Gieling, and H.J. Lieth. 2008. Technical equipment in soilless production systems, p. 157-207. In: Raviv, M. and H.J. Lieth (eds.). Soilless culture: Theory and practice. Elsevier, Amsterdam, The Netherlands.
Varlagas, H., D. Savvas, G. Mouzakis, Ch. Liotsos, I. Karapanos, and N. Sigrimis. 2010. Modelling uptake of $\mathrm{Na}^{+}$and $\mathrm{Cl}^{-}$by tomato in closedcycle cultivation systems as influenced by irrigation water salinity. Agr. Water Mgt. 97: 1242-1250.

Wang, W. 1987. Root elongation method for toxicity testing of organic and inorganic pollutants. Environ. Toxicol. Chem. 6:409414 